\title{
Pure or Complex Hereditary Spastic Paraplegia Type 4?
}

\author{
Josef Finsterer \\ Krankenanstalt Rudolfstiftung, \\ Messerli Institute, \\ Veterinary University of Vienna, \\ Vienna, Austria
}

Received November 12, 2018

Revised December 4, 2018

Accepted December 5, 2018

\section{Correspondence}

Josef Finsterer, $\mathrm{MD}, \mathrm{PhD}$

Krankenanstalt Rudolfstiftung,

Messerli Institute,

Veterinary University of Vienna,

Postfach 20, 1180 Vienna, Austria

Tel +43-1-71165-72085

Fax $+43-1-4781711$

E-mail fifigs1@yahoo.de
Dear Editor,

We read with interest the article by Yang et al. ${ }^{1}$ about a 45 -year-old male with hereditary spastic paraplegia (HSP) due to the mutation c.1413A $>\mathrm{G}$ in SPAST. Below we present our comments and concerns about their study.

It is interesting that the reported patient did not present with muscle weakness but only isolated lower limb spasticity. ${ }^{1}$ In addition to spasticity and muscle weakness, pure forms of HSP may also present with sensory disturbances or urinary dysfunction. Readers should therefore have been informed about whether the reported patient developed muscle weakness, bladder dysfunction, or sensory disturbances as the disease progressed during follow-up.

HSP type 4 (HSP4) may present as either the pure or complex form of HSP. Manifestations in addition to those found in pure forms of HSP4 include tremor, ${ }^{2}$ neuropathy, ${ }^{3}$ epilepsy, ${ }^{4}$ upper limb spasticity, ataxia,${ }^{5}$ white-matter lesions, ${ }^{6}$ cognitive impairment, ${ }^{6}$ an abnormal rear skull pit, and recurrent stillbirths. Although the patient presented with the pure form on admission, it should also have been reported whether he developed any of these features during long-term follow-up.

HSP therapy is usually symptomatic and particularly directed toward the application of physiotherapy, use of walking aids, and administration of antispastics, anticholinergics for bladder dysfunction, and antiepileptic drugs in the case of epilepsy. The types of treatment that were recommended to the patient should have been reported, as well as their effectiveness.

Since the mother of the index case presented with a phenotype similar to that of her son and carried the same mutation, it is another item of missing information whether she developed a complex type of HSP4 during follow-up, as age at onset of the clinical manifestations was the same in both patients.

Lastly, it should be mentioned that at least SPG1 to SPG79 (i.e., not only to SPG72) have been identified thus far, and that $>65$ HSP proteins (i.e., not only 50 ) have been detected. ${ }^{7.8}$

Overall, this interesting case report would have been more meaningful if long-term followup data had been provided, as well as the therapeutic measures applied to the index case and his mother.

\section{Conflicts of Interest}

The author has no potential conflicts of interest to disclose.

\section{REFERENCES}

1. Yang J, Seo JY, Lee KW, Park HM. Novel pathogenic variant of SPAST $(c .1413+4 A>G)$ in a patient with hereditary spastic paraplegia. J Clin Neurol 2019;15:120-121.

2. De Bot ST, Van den Elzen RT, Mensenkamp AR, Schelhaas HJ, Willemsen MA, Knoers NV, et al. Hereditary spastic paraplegia due to SPAST mutations in 151 Dutch patients: new clinical aspects and 27 novel mutations. J Neurol Neurosurg Psychiatry 2010;81:1073-1078.

3. Kumar KR, Sue CM, Burke D, Ng K. Peripheral neuropathy in hereditary spastic paraplegia due to spastin (SPG4) mutation--a neurophysiological study using excitability techniques. Clin Neurophysiol

@ This is an Open Access article distributed under the terms of the Creative Commons Attribution Non-Commercial License (https://creativecommons.org/licenses/by-nc/4.0) which permits unrestricted non-commercial use, distribution, and reproduction in any medium, provided the original work is properly cited. 
2012;123:1454-1459.

4. Bertelli M, Cecchin S, Lorusso L, Sidoti V, Fabbri A, Lapucci C, et al. Identification of a novel mutation in the spastin gene (SPG4) in an Italian family with hereditary spastic paresis. Panminerva Med 2006;48: 193-197.

5. Nielsen JE, Johnsen B, Koefoed P, Scheuer KH, Grønbech-Jensen M, Law I, et al. Hereditary spastic paraplegia with cerebellar ataxia: a complex phenotype associated with a new SPG4 gene mutation. Eur J Neurol 2004;11:817-824.
6. Ribaï P, Depienne C, Fedirko E, Jothy AC, Viveweger C, Hahn-Barma $\mathrm{V}$, et al. Mental deficiency in three families with SPG4 spastic paraplegia. Eur J Hum Genet 2008;16:97-104.

7. Roeben B, Schüle R, Ruf S, Bender B, Alhaddad B, Benkert T, et al. SERAC1 deficiency causes complicated HSP: evidence from a novel splice mutation in a large family. J Med Genet 2018;55:39-47.

8. Koh K, Ishiura H, Tsuji S, Takiyama Y. JASPAC: Japan Spastic Paraplegia Research Consortium. Brain Sci 2018;8:153. 